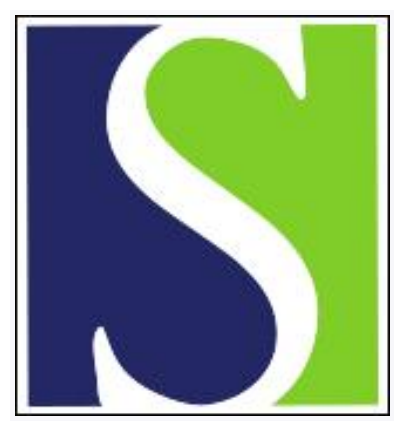

Scand J Work Environ Health 1995;21(4):296-300

https://doi.org/10.5271/sjweh.42

Issue date: Aug 1995

\title{
Lead intoxication caused by skeletal disease
}

by Berlin K, Gerhardsson L, Börjesson J, Lindh E, Lundström N, Schütz A, Skerfving S, Edling C

The following article refers to this text: 2006;32(3):185-189

Key terms: bone fracture; idiopathic osteoporosis; lead worker

This article in PubMed: www.ncbi.nlm.nih.gov/pubmed/8553006

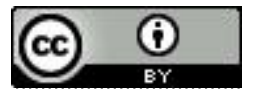




\title{
Lead intoxication caused by skeletal disease
}

\author{
by Klas Berlin, MD, ${ }^{1}$ Lars Gerhardsson, MD, ${ }^{2}$ Jimmy Börjesson, MSc, ${ }^{3}$ Erik Lindh, MD, ${ }^{4}$ \\ Nils Lundström, MD, ${ }^{5}$ Andrejs Schütz, PhD, ${ }^{2}$ Staffan Skerfving, MD, ${ }^{2}$ Christer Edling, $M D^{1}$
}

\begin{abstract}
Berlin K, Gerhardsson L, Börjesson J, Lindh E, Lundström N, Schütz A, Skerfving S, Edling C. Lead intoxication caused by skeletal disease. Scand J Work Environ Health 1995;21:296-300.
\end{abstract}

\begin{abstract}
Background Inorganic lead is accumulated in the skeleton, which harbors more than $90 \%$ of the body burden of lead. If rapidly mobilized, this pool may constitute a health risk. However, clear evidence of this theory has been lacking.

History A previously healthy 36 -year-old Swedish man with more than 10 years of work-related lead exposure developed headache, musculoskeletal pain, and paresthesia of both arms. Two months after the cessation of exposure, the lead level in his blood (B-Pb) was $5.5 \mu \mathrm{mol} \cdot \cdot^{-1}$, and treatment with chelating agents was started. Shortly after the treatment period, he had an accident causing a fracture of the right collum femoris. The $\mathrm{B}-\mathrm{Pb}$ was fairly stable around $1.5 \mu \mathrm{mol} \cdot \mathrm{l}^{-1}$ for about two years after the end of exposure (95th percentile $0.6 \mu \mathrm{mol}$. $1^{-1}$ for occupationally unexposed Swedish men). The examination showed that the patient had high skeletal turnover and clearly reduced bone density, as well as signs of tubular dysfunction. He was given the diagnosis idiopathic osteoporosis. His moderately raised bone lead concentration (about $20 \mu \mathrm{g} \cdot \mathrm{g}$ wet weight ${ }^{-1}$; normal level in Sweden $4 \mu \mathrm{g} \cdot \mathrm{g}^{-1}$ ) can only partly explain the raised $\mathrm{B}-\mathrm{Pb}$, remaining for years after the cessation of exposure. Instead, the main explanation is probably the increased skeletal turnover.
\end{abstract}

Conclusions A combination of a moderately increased bone lead pool and skeletal disease seems to increase the risk for lead poisoning.

Key terms bone fracture, idiopathic osteoporosis, lead worker.

Inorganic lead has a widespread use in industry and in the global environment in many societies (1). More than $90 \%$ of the lead body burden is in the skeleton (2). The bone lead concentration varies considerably in different parts of the world. A total content of approximately a few milligrams has been observed in bones from prehistoric individuals (3). Measurements in contemporary Scandinavians have yielded levels in finger bone and tibia of a few micrograms per gram of bone $(4,5$, Börjesson et al, unpublished report) corresponding to $10-30 \mathrm{mg}$, and higher values, about $100 \mathrm{mg}$, have been reported for occupationally unexposed subjects in, for example, the United Kingdom $(2,6)$ and the United States $(3,7)$. Lead workers may have very high skeletal lead levels, up to $130 \mu \mathrm{g} \cdot \mathrm{g}^{-1}$ in finger bone $(4,8,9)$, corresponding to a total content of about $1 \mathrm{~g}$.

The metabolism of lead probably involves more than one lead pool. A five-compartment model has been sug- gested (10), including plasma and extracellular fluid, blood cells, soft tissues such as liver and kidney, trabecular bone, and cortical bone. The biological half-time in blood and soft tissues is about one month for occupationally unexposed subjects $(9,11,12)$. It is considerably longer, probably a couple of years, for trabecular bone (4) and about a decade for some cortical bones $(9,13)$.

Numerous negative health effects have been related to lead exposure. Lead may cause peripheral neuropathy, encephalopathy, and kidney damage (1). Interstitial nephritis and tubular and glomerular damage have been observed. Early adverse tubular effects include the leakage of enzymes, such as N-acetyl B-glucosaminidase (NAG) from tubular cells, as well as the excretion of low (eg, $\mathrm{B}_{2}$-microglobulin and retinol binding protein) and high molecular-weight proteins (eg, albumin) into the urine (14).

1 Department of Occupational Medicine, University Hospital, Uppsala, Sweden.

2 Department of Occupational and Environmental Medicine, University Hospital, Lund, Sweden.

3 Department of Radiation Physics, University Hospital, Malmö, Sweden.

4 Department of Medicine, University Hospital, Uppsala, Sweden.

5 Primary Health Care Center, Grangärde, Sunnansjö, Sweden.

Reprint requests to: Dr Klas Berlin, Department of Occupational Medicine, University Hospital, S-751 85 Uppsala, Sweden. 
Lead in bone is of scientific and clinical interest for several reasons. Lead in bone can be used as an index of previous lead exposure $(4,5,8,15)$. Because of continuous mobilization, the bone pool is a source of endogenous exposure to lead, which in long-term exposed lead workers may be considerable $(4,5,8,9)$. Skeletal lead may probably be mobilized by physiological and pathological conditions, such as nutritional deficiencies, pregnancy, lactation, and osteoporosis (16), although such an occurrence has not been clearly demonstrated. It has even been claimed that extensive destruction of the skeleton of lead-exposed subjects, for example, by bone tumors $(17,18)$ or osteoporosis $(19,20)$, has caused endogenous lead toxicity and adverse health effects in other organs. However, the evidence is not conclusive.

The determination of lead in bone may be performed in vivo by X-ray fluorescence techniques $(8,9,13,15$, $21-23)$. Such determinations are safe, rapid, and noninvasive, and the low skin and whole-body radiation dose equivalents give a negligible risk of adverse radiological health effects.

This report describes a case of endogenous lead exposure causing lead toxicity in a worker exposed longterm to lead; he had a moderately increased body burden of lead after the diagnosis of a rare male skeletal disease.

\section{Case history}

A previously healthy 36-year-old Swedish man had worked scrap-cutting lead-painted metal constructions for more than 10 years. Early in 1992, he had two months of sick-leave because of diffuse symptoms such as headache, multifocal musculoskeletal pain, and paresthesia of both arms. From September to December in 1991, he had worked intensively scrap-cutting 12 lead-painted locomotives. Personal protective breathing devices were never used.

At the end of the sick-leave period, a blood sample was taken that showed a blood lead (B-Pb) level of $5.5 \mu \mathrm{mol} \cdot \mathrm{I}^{-1}$ [95th percentile $0.6 \mu \mathrm{mol} \cdot \mathrm{I}^{-1}$ in occupationally unexposed Swedish men (24)]. The patient was immediately hospitalized and administered chelation therapy. Initially, penicillamine $(500 \mathrm{mg}$ ) was given orally every $6 \mathrm{~h}$, in combination with vitamin $\mathrm{B}_{6}, 40 \mathrm{mg}$ every $8 \mathrm{~h}$. On the second day, penicillamine was substituted with dimercaptosuccinic acid (DMSA), $10 \mathrm{mg} \cdot \mathrm{kg}^{-1}$ body weight ${ }^{-1}$, which was given orally every $8 \mathrm{~h}$ for another $5 \mathrm{~d}$. When the patient left the hospital, his $\mathrm{B}-\mathrm{Pb}$ had decreased to $1.5 \mu \mathrm{mol} \cdot \mathrm{l}^{-1}$.

Three weeks later, during sick leave, the patient stumbled and fell to the ground, which caused a hip fracture (right collum femoris) requiring external pin fixation at a local hospital. During the treatment period, the $\mathrm{B}-\mathrm{Pb}$ slightly increased to about $1.9 \mu \mathrm{mol} \cdot 1^{-1}$. Thereafter, it has been fairly stable, around $1.5 \mu \mathrm{mol} \cdot \mathrm{l}^{-1}$ for almost two years without further occupational lead exposure.

Because of the high $\mathrm{B}-\mathrm{Pb}$, without any known current lead exposure, the patient had a detailed examination in November 1992.

The patient was a heavy smoker with a consumption of 20-30 cigarettes per day since the age of 15 years. His alcohol consumption was higher than for the general population in Sweden, but not extreme.

He had a height of $192 \mathrm{~cm}$ and weighed $93 \mathrm{~kg}$.

No remarkable findings were made in the general physical examination. The patient was fully oriented. His mental status, cranial nerves, and motor function (including strength, coordination, and gait) were all normal. His pupils reacted normally to light and his arm and leg reflexes were normal. His blood pressure was within normal limits, $140 / 80 \mathrm{~mm} \mathrm{Hg}(18.6 / 10.6 \mathrm{kPa})$.

The lead concentration in finger bone was determined by X-ray fluorescence using a ${ }^{57} \mathrm{Co}$ source [detection limit $18 \mu \mathrm{g} \cdot \mathrm{g}$ wet weight ${ }^{-1}$, precision $15 \%$ (8)]. The patient showed a concentration of $20 \mu \mathrm{g} \cdot \mathrm{g}$ wet weight ${ }^{-1}$. This level corresponds to about $34 \mu \mathrm{g} \cdot \mathrm{g}$ bone mineral $^{-1}$ (15). The $\mathrm{B}-\mathrm{Pb}$ was $1.75 \mu \mathrm{mol} \cdot \mathrm{l}^{-1}$. Later, in March of 1993, a bone lead determination of a bone biopsy from the right iliac crest region (mainly trabecular bone) was performed by atomic absorption spectrophotometry. This analysis yielded a similar figure of about $21.7 \mu \mathrm{g} \cdot \mathrm{g}$ dry weight $^{-1}$

Bone density measurements by dual energy X-ray absorptiometry (Lunar DPX-C equipment) in vertebral body and femur showed values which were less or equal to about $75 \%$ of normal density (comparable to values for a 75-year-old man). The level of hydroxyproline in urine was within normal limits $(15.9 \mathrm{mmol} \cdot \mathrm{mol}$ creatinine ${ }^{-1}$, but the concentration of osteocalcine in serum was elevated $\left(16.8 \mu \mathrm{g} \cdot 1^{-1}\right)$, indicating a high turnover in the bone-forming osteoblasts, but less activity in the bone-resorbing osteoclasts. These values must be interpreted, however, with caution, as individual day-to-day variation is considerable.

After tetracycline labeling by peroral intake of oxytetracycline, $250 \mathrm{mg}$ four times daily, on day 1,2,13 and 14 , bone biopsy was performed on day 19 . The biopsy showed no signs of osteomalacia.

All of the hormone measurements showed concentrations within normal limits. The serum level was $2.9 \mathrm{mU} \cdot 1^{-1}$ for thyrotropin (normal range $0.3-$ $4.0 \mathrm{mU} \cdot 1^{-1}$ ), $27 \mathrm{ng} \cdot \mathrm{l}^{-1}$ for parathyroid hormone (measured as intact hormone; normal range $\left.12-55 \mathrm{ng} \cdot \mathrm{l}^{-1}\right)$, $33 \mathrm{nmol} \cdot 1^{-1}$ for testosterone (normal range 10 $45 \mathrm{nmol} \cdot 1^{-1}$ ), $9.8 \mu \mathrm{g} \cdot 1^{-1}$ for prolactin (normal range for males $<15 \mu \mathrm{g} \cdot 1^{-1}$ ) and $190 \mu \mathrm{g} \cdot 1^{-1}$ for insulin-like growth factor 1 (IGF-1, normal range $150-450 \mu \mathrm{g}$. $\left.1^{-1}\right)$. The serum levels of vitamin $D$ were also within normal limits: $1.25(\mathrm{OH})_{2}$-vitamin D $25 \mathrm{ng}^{-\mathrm{l}^{-1}}$ (normal range $\left.20-60 \mathrm{ng} \cdot \mathrm{l}^{-1}\right)$ and $\mathrm{S}-25-\mathrm{OH}$-vitamin $\mathrm{D}_{3} 22 \mu \mathrm{g} \cdot \mathrm{l}^{-1}$ 
(range $15-65 \mu \mathrm{g} \cdot \mathrm{l}^{-1}$ ).

The blood cell sedimentation rate was $6 \mathrm{~mm} \cdot \mathrm{h}^{-1}$ and the hemoglobin level was $151 \mathrm{~g} \cdot \mathrm{l}^{-1}$. The routine blood chemistry was normal, including red and white cell counts. The serum enzyme activity of possible liver origin was within normal limits with the exception of $\gamma$ glutamyl transpeptidase, which was slightly elevated, $0.67 \mu \mathrm{kat} \cdot \mathrm{I}^{-1}$ (upper reference limit $0.60 \mu \mathrm{kat} \cdot \mathrm{I}^{-1}$ ). The direct and total bilirubin levels, alkaline phosphatase, lactate dehydrogenase, cholesterol, triglycerides, albumin, calcium, phosphate, and creatinine in blood or serum were all within normal ranges. The $\mathrm{B}_{2}$-microglobulin in plasma was $1.35 \mathrm{mg} \cdot 1^{-1}$, the cadmium in blood was $20 \mathrm{nmol} \cdot 1^{-1}$ (95th percentile for occupationally unexposed smoking Swedes $31 \mathrm{nmol} \cdot \mathrm{l}^{-1} ; 4 \mathrm{nmol} \cdot \mathrm{l}^{-1}$ for nonsmokers), and the selenium in plasma was $66 \mu \mathrm{g} \cdot \mathrm{I}^{-1}$.

The albumin in urine was normal, as well as the urinary checks with dip-sticks (Ecur-4 test; Boehringer Mannheim, Germany) for signs of albumin, glucose, erythrocytes, and leukocytes. The lead in urine was $18.4 \mu \mathrm{mol} \cdot \mathrm{mol}_{\text {creatinine }}{ }^{-1}$, urinary NAG $2.42 \mathrm{U} \cdot \mathrm{mmol}$ creatinine $^{-1}$ (normal value $<0.7$ ), the urinary cadmium $0.58 \mu \mathrm{mol} \cdot \mathrm{mol}$ creatinine $^{-1}$, and the urinary calcium $122 \mathrm{mg} \cdot \mathrm{I}^{-1}$.

\section{Discussion}

The patient presented in this paper had suffered massive lead exposure, which caused nephropathy. However, the exposure had been rather short and had induced moderately increased lead levels in bone, as shown by the in vivo $\mathrm{X}$-ray measurements of the cortical bone and the chemical analysis of trabecular bone. In addition, he had idiopathic osteoporosis, with increased skeletal turnover causing reduced bone density and a pathological fracture. The enhanced mobilization of bone resulted in an increased concentration of $\mathrm{B}-\mathrm{Pb}$, which remained long after the cessation of exposure and which was as much as about four times higher than the average $\mathrm{B}-\mathrm{Pb}$ in the occupationally unexposed population and also higher than expected from the lead levels in his skeleton. The high $\mathrm{B}-\mathrm{Pb}$ had caused early signs of renal tubular dysfunction. Thus this case shows that the combination of moderately increased bone-lead concentration and skeletal disease increases the risk of lead poisoning.

Before the skeletal disease was revealed by the fracture, the patient had suffered an episode of lead neuropathy, as indicated by symptoms, signs, and the $\mathrm{B}-\mathrm{Pb}$ level. The initial $\mathrm{B}-\mathrm{Pb}$ of $5.5 \mu \mathrm{mol} \mathrm{Pb} \cdot \mathrm{1}^{-1}$, determined about two months after the cessation of exposure, was very high. The average "normal" value for unexposed men in Sweden is only about $0.4 \mu \mathrm{mol} \cdot l^{-1}(24)$. The biological threshold limit in Sweden is $2.5 \mu \mathrm{mol} \cdot \mathrm{H}^{-1}$. It can be assumed that at least one biological half-time for the fast phase in a two-phase elimination pattern (11) had passed before the first blood lead measurement was taken; therefore the $\mathrm{B}-\mathrm{Pb}$ value was probably around $10 \mu \mathrm{mol} \cdot \mathrm{I}^{-1}$ at the end of exposure.

It is unlikely that the endogenous lead exposure from the skeleton played any major role in the neuropathy. However, such exposure may very well be the cause of the patient's clearly elevated concentration of NAG in urine. An increased urinary excretion of NAG has been observed in previous studies of lead-exposed workers $(25,26)$. It has been suggested that urinary NAG activity is a sensitive marker for early stages of lead nephropathy (27). The possibility that the transient massive lead exposure was the cause of the tubular dysfunction, which was diagnosed 10 months later, must be considered. However, the elevation of urinary NAG in lead workers is only temporary after the end of exposure (28). Thus it seems likely that the dysfunction was due to continuous endogenous lead exposure from the skeleton.

The lead worker had a $\mathrm{B}-\mathrm{Pb}$ value of around $1.5 \mu \mathrm{mol} \cdot 1^{-1}$ for almost two years after the cessation of exposure, although the bone lead measurements of the finger gave a value of $20 \mu \mathrm{g} \cdot \mathrm{g}$ wet bone $\mathrm{e}^{-1}$. This $\mathrm{B}-\mathrm{Pb}$ value is unproportionally high, since previous studies of retired lead workers (8) have shown that a $\mathrm{B}-\mathrm{Pb}$ of about $1.5 \mu \mathrm{mol} \cdot 1^{-1}$ corresponds to bone lead concentrations of about $100 \mu \mathrm{g} \cdot \mathrm{g}$ wet bone $\mathrm{e}^{-1}$ in the finger. Thus the unexpectedly high $\mathrm{B}-\mathrm{Pb}$ of our patient was probably the result of an abnormally high endogenous exposure caused by his skeletal disease.

Lead may affect bone function in several ways, for example, indirectly by reducing circulating levels of 1,25-dihydroxycholecalciferol, as shown in lead-exposed children (29). However, these levels were normal in our lead worker. Lead may also directly alter bone cell function by disturbing the response to hormonal stimulation. For example, low concentrations of lead may inhibit the 1,25-dihydroxy vitamin $\mathrm{D}_{3}$-stimulated osteoblast synthesis of osteocalcin, a calcium-binding protein (30). Then, lead may impair the ability of cells to synthesize or secrete other components of the bone matrix, such as collagen or bone sialoproteins. Anderson et al (31) observed that lead intoxication decreased oppositional rates, radial closure rates, activation frequency, bone formation rate, and increased osteon formation time for beagle dogs exposed for almost seven months. These results indicate that lead exposure decreases bone formation rates at all three levels of skeletal organization (31). Possibly, as a result of lead effects on the skeleton, an inverse relationship has been reported between $\mathrm{B}-\mathrm{Pb}$ value and age-related height in children (32). Effects pointing in the same direction have been reported by other authors (33-35).

Thus the possibility that, in our patient, the lead exposure was the cause of the skeletal disease must be considered. However, it seems unlikely, as the bone-lead 
accumulation was only moderate, while the bone disease was severe. Accordingly, the opposite seems much more likely (ie, that the bone disease was the cause of the lead mobilization and thereby also the cause of the negative health effects).

Osteoporosis is a term used to describe a group of diseases of diverse etiology, which is characterized by a reduction in the mass of bone unit volume to a level below that required for adequate mechanical support function. Idiopathic osteoporosis is the term used to describe the disorder in young men and in premenopausal women if no other etiologic factor is discovered. This disease is very rare in Scandinavia, affecting approximately 40 adult men in all age groups in Sweden, which has a total population of 8.8 million people. The course of the disorder varies. Recurrent episodes of fractures, even after minor trauma, as in our patient, are characteristic. However, progressive deterioration does not occur in all patients, and in some the clinical problem is rather benign.

As only a small proportion of the working population has occupational lead exposure, the combination of the rare syndrome idiopathic osteoporosis and lead work, as described in this report, is truly unique. However, it is of interest, as other pathological conditions of the bone may be more important, such as osteolytic tumors or osteoporosis caused by immobilization.

\section{Acknowledgments}

This work was supported by the Swedish Work Environment Fund and the Medical Faculty of the Lund University in Lund.

\section{References}

1. Environmental Protection Agency (EPA). Air quality criteria for lead. Research Triangle Park (NC): EPA, Environmental Criteria and Assessment Office, 1986. EPA-600/8-83/028aF, vol I-IV.

2. Barry PSI. A comparison of concentrations of lead in human tissues. Br J Ind Med 1975;32:119—39.

3. Ericson JE, Shirahata H, Patterson CC. Skeletal concentration of lead in ancient Peruvians. N Engl J Med 1979;300: 946-51.

4. Schütz A, Skerfving S, Christoffersson JO, Ahlgren L, Mattsson $S$. Lead in vertebral bone biopsies from active and retired lead workers. Arch Environ Health 1987;42:340 -6.

5. Gerhardsson L, Attewell R, Chettle DR, Englyst V, Lundström N-G, Nordberg GF, et al. In vivo measurements of lead in bone in long-term exposed lead smelter workers. Arch Environ Health 1993;48:147-56.

6. Crawford MD, Crawford T. Lead content of bones in a soft and a hard water area. Lancet 1969;1:699-701.

7. Gross SB, Pfitzer EA, Yeager DW, Kehoe DA. Lead in human tissues. Toxicol Appl Pharmacol 1975;32:638-51.

8. Christoffersson JO, Schütz A, Ahlgren L, Haeger-Aronsen B, Mattsson S, Skerfving S. Lead in finger-bone analysed in vivo in active and retired lead workers. Am J Ind Med 1984;6: $447-57$.

9. Nilsson U, Attewell R, Christoffersson JO, Schütz A, Ahlgren $\mathrm{L}$, Skerfving S, et al. Kinetics of lead in bone and blood after end of occupational exposure. Pharmacol Toxicol 1991;68: 477-84.

10. Skerfving S, Nilsson U, Schütz A, Gerhardsson L. Biological monitoring of inorganic lead. Scand $\mathbf{J}$ Work Environ Health 1993;19 suppl 1:59-64.

11. Schütz A, Skerfving S, Ranstam J, Christoffersson JO. Kinetics of lead in blood after the end of occupational exposure. Scand J Work Environ Health 1987;13:221 - 31 .

12. Rabinowitz MB, Wetherill GW, Kopple JD. Kinetic analysis of lead metabolism in healthy humans. J Clin Invest 1976:58:260-70.

13. Christoffersson JO, Ahlgren L, Mattsson S, Schütz A, Skerfving $S$. Decrease of skeletal lead levels in man after end of occupational exposure. Arch Environ Health 1986;41:312-8.

14. Gerhardsson L, Chettle DR, Englyst V, Nordberg GF, Nyhlin $\mathrm{H}$, Scott MC, et al. Kidney effects in long term exposed lead smelter workers. Br J Ind Med 1992;49:186-92.

15. Somervaille LJ, Nilsson U, Chettle DR, Tell I, Scott MC, Schütz A, et al. In vivo measurements of bone lead - a comparison of two $\mathrm{x}$-ray fluorescence techniques used at three different bone sites. Phys Med Biol 1989;34:1833-45.

16. Silbergeld EK, Sauk J, Somerman M, Todd A, McNeill F, Fowler B, et al. Lead in bone: storage site, exposure source, and target organ. Neurotoxicology 1993;14:225-36.

17. Brown A, Tompsett SL. Poisoning due to mobilization of lead from the skeleton by leukaemic hyperplasia of bone marrow. Br Med J 1945;2:764 - 5.

18. Brown A. The lead content of the blood and its relation to rarefying processes in bone. Q J Med 1946;15:77-90.

19. Shannon M, Lindy H, Anast C, Graef J. Recurrent lead poisoning in a child with immobilization osteoporosis. Vet Hum Toxicol 1988;30:586-8.

20. Markowitz ME, Weinberger HL. Immobilization-related lead toxicity in previously lead-poisoned children. Pediatrics 1990; 86:455-7.

21. Ahlgren L, Lidén K, Mattsson S, Tejning S. X-ray fluorescence analysis of lead in human skeleton in vivo. Scand $\mathfrak{J}$ Work Environ Health 1976;2:82-6.

22. Ahlgren L, Haeger-Aronsen B, Mattsson S, Schütz A. In-vivo determination of lead in the skeleton after occupational exposure to lead. Br J Ind Med 1980;37:109—13.

23. Nilsson U, Skerfving $S$. In vivo X-ray fluorescence measurements of cadmium and lead. Scand J Work Environ Health 1993;19 suppl 1:54—8.

24. Svensson BG, Björnham $\AA$, Schütz A, Lettevall U, Nilsson A, Skerfving $S$. Acidic deposition and human exposure to toxic metals. Sci Total Environ 1987;67:101-15.

25. Meyer BR, Fischbein A, Rosenman K, Lerman Y, Drayer DE, Reidenberg MM. Increased urinary enzyme excretion in workers exposed to nephrotoxic chemicals. Am J Med 1984;76: $989-98$.

26. Verschoor M, Wibowo A, Herber R, van Hemmen J, Zielhuis $\mathrm{R}$. Influence of occupational low-level lead exposure on renal parameters. Am J Ind Med 1987;12:341-51.

27. Bernard A, Lauwerys R. Epidemiological application of early markers of nephrotoxicity. Toxicol Lett 1989;46:293-306.

28. Coratelli P, Giannattasio M, Lomonte C, Marzolla R, Rana F, L'Abbate N. Enzymuria to detect tubular injury in workers exposed to lead: a 12-month follow-up. Contrib Nephrol $1988 ; 68: 207-11$. 
29. Mahaffey KR, Rosen JF, Chesney RW, Peeler JT, Smith CM, DeLuca HF. Association between age, blood lead concentration, and serum 1,25-dihydroxycholecalciferol levels in children. Am J Clin Nutr 1982;35:1327-31.

30. Pounds JG, Long GJ, Rosen JF. Cellular and molecular toxicity of lead in bone. Environ Health Perspect 1991;91: $17-32$.

31. Anderson C, Danylchuk KD. The effect of chronic low level lead intoxication on the Haversian remodeling system in dogs. Lab Invest 1977;37:466-9.

32. Schwartz J, Angle C, Pitcher H. Relationship between childhood blood lead levels and stature. Pediatrics 1986;77:2818.
33. Lauwers MC, Hauspie RC, Susanne C, Verheyden J. Comparison of biometric data of children with high and low levels of lead in the blood. Am J Phys Anthropol 1986;69:107-16.

34. Angle CR, Huseman CA. Childhood blood lead: growth and neuroendocrine toxicity. Vet Human Toxicol 1989;31:341.

35. Shukla R, Bornschein RL, Dietrich KN, Buncher CR, Berger OG, Hammond PB, et al. Fetal and infant lead exposure: Effects on growth in stature. Pediatrics 1989;84:604-12

Received for publication: 26 August 1994 